\title{
Uncertainty, bounded rationality and post-Keynesian Macroeconomics
}

\author{
Finn Olesen ${ }^{*}$
}

\begin{abstract}
As a core element in mainstream neoclassical theory we assume that economic agents behave rationally. They have full information about everything of economic relevance at present, as well as concerning the future. They either maximize their profit or their utility. Is the model of the rational economic man realistic and a useful concept? According to post-Keynesians and the school of bounded rationality (e.g. the works of Herbert Simon and others) the answer to this question is ,Nor. In this paper we discuss some aspects of bounded rationality and the position taken by Keynes and by the post-Keynesians who argued that actual behaviour is restricted and less than perfect due to the existence of fundamental uncertainty as pointed out by Keynes in his General Theory. Therefore, the macroeconomic system should be seen as an open, changeable and path-dependent system.

JEL classifications: $B_{22}, B_{41}, E_{I 2}$

Keywords: uncertainty, bounded rationality, post-Keynesian economics
\end{abstract}

\section{Introduction}

Ever since the birth of economics dating back to Adam Smith's The Wealth of Nations economists have been concerned with the behaviour of households and firms. And out of the classical writings - especially those of David Ricardo and John Stuart Mill, combined with

* University of Southern Denmark. The author is very grateful to two anonymous referees for their valuable comments and suggestions. The usual disclaimer applies.

Correspondence Address:

Associate Professor Finn Olesen, Department of Environmental and Business Economics, University of Southern Denmark, Niels Bohrs Vej 9- I0, DK-670o Esbjerg, Denmark, e-mail: finn@sam.sdu.dk.

Received 03 October 2008, accepted 23 June 2009

(C) INTERVENTION 7 (I), 20IO, IO9-I24 
what later came to be known as the Marginal Revolution - emerged the vision of the rational economic man which was eventually fully unfolded in modern neoclassical theory. ${ }^{\mathrm{T}} \mathrm{Ra}$ tional economic man has full information about everything of relevance in the economy at present as well as in the future. He maximises and strives for optimality, and he is very successful in achieving both. As a consequence of his apparent success, he has conquered not only the standard textbooks of microeconomics but also those of modern macroeconomics, operating within a framework of a general inter-temporal equilibrium context.

Is the stipulated behaviour of the rational economic man indeed representative of how households and firms actually conduct their economic affairs? Seen from the perspective of the advocates of bounded rationality (Herbert Simon and others) the answer is a definite 'No . Out there in real life economic agents seem to be satisficing agents doing the best they possibly can to seek out the better among the second-best solutions to their various complex economic problems. First-best solutions might be attractive as a vision or ideal of how agents should behave, i.e. how they should choose between optimums. However, this is in conflict with the empirical evidence we have in front of us; this is the message imparted by the school of bounded rationality.

Being critical of mainstream neoclassical economics is by no means new. Critique has a long history. When Keynes in 1936 published his General Theory, he not only launched a severe attack on mainstream neoclassical thinking (theoretically as well as methodologically), he also offered a promising alternative. With Keynes we have come to learn that economic agents must make their decisions based on imperfect knowledge of a truly uncertain and very changeable future. Economic agents form and maintain expectations upon which they act as best they can in a non-ergodic environment. In so doing, they cannot behave as rational economic men would have done. In this respect at least, it seems as if advocates of bounded rationality and the post-Keynesians - following Keynes's revolutionary works argue along the same lines: Individuals' economic behaviour is bound to be less than perfect. Nevertheless, the perspective of the post-Keynesians differs from that of the advocates of bounded rationality. For post-Keynesians, opposed to the school of bounded rationality, households and firms have to behave in a restricted way not because of a lack of cognitive abilities, but because they act in an economic environment with a fundamental type of uncertainty. It is this kind of uncertainty that causes decision-making at the individual level to be troublesome and certainly less than perfect.

To assume that we behave less-than-perfectly because we lack certain cognitive capacities is problematic in itself. It can lead to an economic outcome characterized by disequilibrium, micro-economically as well as macro-economically. However, these problems can at least be dealt with, insofar as we can learn more and thereby gain additional knowledge

I For a discussion of how the economic man of Adam Smith - a man who was a complex mixture of instincts, talents, motivations, and preferences - gradually developed (from the homo economicus of John Stuart Mill in I836, to the I87I calculating consumer of Jevons, and the I9I5 neoclassical slot machine man of Frank Knight) into a sterile model man in economic theory who primarily lived his life inside the mathematical laboratory of economists, see the presentation in Morgan (2006). 
about the economic processes over time, e.g. better education, applying >rules-of-thumb and so on. More important, however, are those problems that emerge from the existence of a fundamental type of uncertainty. It is not easy to try to overcome this kind of lack of knowledge. This fundamental uncertainty - as I will demonstrate in this paper - makes the macroeconomic universe quite different from that of the modern macroeconomic mainstream, which operates on the premise of rational economic man. Seen from the perspective of Keynes and the post-Keynesians »time, uncertainty and money" are core elements which have to be addressed when we try to elaborate and develop our understanding of the workings of a modern economy. This is the vision of the post-Keynesian alternative to modern macroeconomic mainstream, be it New Classical or New Keynesian macroeconomics.

In the following section, we briefly discuss the rational economic man and his role in economics. Section 3 presents key aspects of the school of bounded rationality, while Section 4 discusses the different approach taken by Keynes and the post-Keynesians. Section 5 discusses the macroeconomic implications that seem to follow from an economic world view (or what Sheila Dow has termed "mode of thought", see Dow [1996]) of accepting or rejecting the premise of full and perfect information in the decision-making process, as represented by the rational economic man. The discussion contrasts the mainstream understanding with a post-Keynesian alternative. Finally the paper is closed with some concluding remarks in Section 6.

\section{Rational economic man: The model for scientific success?}

Robert Heilbroner (2000), discussing the apparent success of mainstream economics, has noted that there exists a fundamental difference between the natural sciences and economics as one of the social sciences. The objects studied by social scientists, including economics, are very different in content (and in the context in which it should be analysed). Economics studies human behaviour. As Heilbroner points out:

»In a word, aside from pure physical reflexes, human behavior cannot be understood without the concept of volition - the unpredictable capacity to change our minds up to the very last moment. By way of contrast, the elements of nature rbehave as they do for reasons of which we know only one thing: the particles of physics do not ichooser to behave as they do [...] If economics were in fact a science, we humans would be mere robots, no more capable of choosing what was to be our response to a price rise than is a particle of iron to the presence of a magnet." (Heilbroner 2000: 317)

The methodology of economics, Heilbroner argues, must be fundamentally different from that of the natural sciences. The environment of economics is generally not characterised by the same homogeneous and stable nature as that of physics. Society will change and develop as history has repeatedly demonstrated. Change and development are also characteristic of economic institutions and of the way humans behave economically. With Alfred 
Marshall, we must accept that economics deals with "the ever-changing and subtle forces of human nature (quoted by Heilbroner 2000: 317).

Since the days of David Ricardo, and the coming of the Marginal Revolution in the I870s, economics has been inclined to copy the perspectives and methods of the natural sciences. We have given ourselves to working as deductive scientists. In mainstream economics, therefore, we have long advocated the use of mathematical formalism when we put forward economic statements and theories, and we have relied on mathematical presentations in our presentation of empirical evidence. Nowadays, hardly any economic article can be published without some mathematical equations and econometrics. However, if society is constantly changing, we cannot, according to Haack (2004: 226-227), rely on such a uniform methodological approach, because

"the objects of social scientific investigation are often local to a particular society and time [...] [and within the social sciences we should therefore rather try to seek] intentional explanations, couched in terms of human agents and their motivation«.

In neoclassical economics we have tried to eliminate the problem of subjectivity in human behaviour by stating that economic agents act within a theoretical framework characterised by perfect inter-temporal knowledge, maximizing utilities and profits. We postulate that human beings try to achieve situations of optimality (first-best solutions). The rational economic man is normally created as a very selfish, rational, calculating and very successful individual. And his rationality is of an instrumental kind. Hence, following Morgan (2006: 2I), we have seen how

"the character of rational economic man thus ceased to have any explanatory power over the causes of economic behavior [...] Model man in this sense is no longer a perfectly distilled version of real man's economic behavior, but a normative model of economic behavior for real people to follow«.

Should economic agents really be modelled as mechanical and deterministic machines? ${ }^{2}$ Nelson disagrees:

"Defining economics as the study of rational choice, neoclassical economics treats human physical bodies, their needs, and their evolved actual psychology of thought and action as irrelevant. The notion that humans are created as rational decisionmakers is, from a physical anthropology point of view, just as ludicrous as the notion that humans were created on the sixth day." (Nelson 2004: 215)

Following Dequech (2007 - 8) and Colander et al. (2007-8), mainstream economics goes beyond that of traditional neoclassical economics. Mainstream economics include behavioural economics, experimental economics, new institutional economics and evolutionary

2 "If economies are deterministic machines, how can human purpose have any effect? If human bodies (including brains) obey the laws of animal nature, how is it that humans are distinguished by free minds? If the world is mechanical, how can it also be moral and valuable?" (Nelson 2004: 213). 
game theory. Although these various components of mainstream economics are all characterized by the traditional economic emphasis on mathematical formalism, Morgan (2006) might be correct in arguing that economists are in the process of refashioning the archetypal model of the rational economic man.

A somewhat different - and more severe - criticism concerning the status of modern economics has been put forward by Mark Blaug:

"Modern economics is sick. Economics has increasingly become an intellectual game played for its own sake and not for its practical consequences for understanding the economic world. Economists have converted the subject into a sort of social mathematics in which analytical rigour is everything and practical relevance is nothing." (Blaug 1997: 3)

Working on the basis of these methodological guidelines both microeconomics and macroeconomics have become theoretical games that could be played with references to actual economic affairs remaining peripheral. According to Blaug, modern economics thereby suppresses, or tries to suppress, the complexity of the economic environment within which individuals act. As a consequence, present-day economics, according to Blaug, has truly become the dismal sciencer, because

"much of modern microeconomics might be fairly described as a kind of geography that consists entirely of images of cities but providing no maps of how to reach a city either from any other city of from the countryside [...] in recent years even macroeconomics has fallen prey to empty formalism« (Blaug 1997: $4-5)^{3}$

\section{Bounded rationality}

As Foley (2004) and Simon (1978 and 1979) have argued, rationality in economic behaviour does not necessary mean that humans have to behave as optimising individuals, as is normally the case within mainstream neoclassical economics. Economic rationality could and should mean something else, as we have learned from empirical evidence. ${ }^{4}$ In economics, we have traditionally used a narrower definition of the term rationality s than we ought to have

3 For a discussion of the formalist revolution in economics in general and its consequences see e.g. Blaug (1999) and Hodgson (2004).

4 With Simon (1979: 510): "There can no longer be any doubt that the micro assumptions of the theory - the assumptions of perfect rationality - are contrary to fact. It is not a question of approximation; they do not even remotely describe the processes that human beings use for making decisions in complex situations." 
done. Instead of regarding individual behaviour as perfectly rational, we should consider a kind of rationality that could be termed `bounded rationality ‘ or 'procedural rationality ${ }^{5}{ }^{5}$

When Herbert Simon was awarded the Nobel Prize in economics in 1978, the prize committee gave special recognition to Simon's early work in the period $1947-58$, when he developed this broader concept of rationality (March 1978). According to Simon, human behaviour is limited in various relevant aspects when humans act as economic agents. Due primarily to a lack of cognitive abilities, individuals are unable to fully process all necessary information. Humans must act on the basis of imperfect knowledge, dealing with an uncertain future, when they make their economic decisions. In real life, economic agents do not optimise and search for first-best solutions. They have to accept less. They are satisfied with achieving useful second-best alternatives by applying >rules of thumb two concepts of ssearching and ssatisficing ‘ are of central importance to Simon and to the advocates of bounded rationality. Nevertheless, Simon's point is that economic agents still behave in a rational way when they accept less-than-perfect economic outcomes. Therefore, the concept of rationality which we use in economic theory ought to have at least some kind of realism incorporated in the definition of the term:

"A theory of rationality that does not give an account of problem solving in the face of complexity is sadly incomplete. It is worse than incomplete; it can be seriously misleading by providing ssolutions` to economic questions that are without operational significance.« (Simon 1978: 9)

While Simon and his followers have studied how firms behave less than perfectly when they have to decide what to produce and what to sell, Daniel McFadden, among others, has studied how households behave when they decide what to consume. To understand this process, we have to acknowledge that besides including one's preferences in the analysis as a key factor, we need to focus upon perceptions/beliefs, attitudes, affects and motives of the individual as relevant parameters in the process of making rational consumption choices. Once again, this becomes a process that shows human beings to be less than perfect when it comes to rational decision-making:

"What stands out is that humans fail to retrieve and process information consistently, and this generates a variety of cognitive anomalies [...] I conclude that perceptionrationality fails, and that the failures are systematic, persistent, pervasive, and large in magnitude. There is also substantial experimental evidence that process-rationality fails, with humans adopting a variety of problem-solving modes, rules, and heuristics rather than monolithic utility maximization.« (McFadden I999: 96 - 97)

Examining empirical evidence concerning the behaviour of firms as well as households, there is no doubt that bounded rationality better corresponds to economic actions than a model

5 A survey discussing the pros and cons of bounded rationality in general can be found in Conlisk (1996). 
based on the perfect rationality of traditional rational economic man. This is the message of Simon, McFadden and others.

\section{The existence of fundamental uncertainty}

With the publication of The General Theory in 1936 Keynes not only attacked mainstream neoclassical economics theoretically as well as methodologically; he also put forward an alternative. Focusing on the behaviour of households and firms, Keynes made it clear that economic agents always act on their expectations when they have to decide what to do in the future. But their expectations are not `rationalı, in the modern macroeconomic understanding of the term. Of course, the households and firms try to achieve the best outcome they possibly can. But individuals have to formulate their expectations on the basis of imperfect knowledge about a truly uncertain future in an economic system that is dynamic, changeable, and path-dependent. So it is almost certain that they will be mistaken in their decision-making processes, at least to some degree.

When households and firms have to decide what to do in the future, they try to assess probable future outcomes. In this regard, as stated by Dequech (1997a and I997b), we have to distinguish between three types of probabilities: unknown, non-numerical and non-comparable. Focusing on the first type of probabilities mentioned by Dequech, if the outcome of future events is unknown to the individual, this could be explained by his or hers lack of cognitive abilities. Should this be the case, the individual could gain some new cognitive skills - for instance, he or she could be better educated by participating in a process of learning by doing; when acting economically, you automatically store knowledge about the workings of the different economic processes, becoming more knowledgeable when having to decide about what to do in the future. In this sense, individuals acquire knowledge so that they are better able to overcome the problems caused by uncertainty.

While this might be representative of the case put forward by the advocates of bounded rationality, this is not the position taken by Keynes or the post-Keynesians. Although Keynes, the post-Keynesians, Simon and others all try to reformulate economic theory so that it accords better with real life economic processes, they differ in their content and approach, as argued by Dunn (200I), Farmer (1995) and Davidson (I996). ${ }^{6}$

6 As Dunn (200I: 569-577) points out: „Discussions of bounded rationality are implicitly conducted in terms of the ergodic axiom - and that in the long run, bounded rationality collapses into the substantive rationality of preprogrammed choices [...] The assumptions of bounded rationality cannot mean in any substantive sense that systematic mistakes will continue to be made in the long run if based on an ergodic conception of economic processes. Ex ante maximization ultimately replaces satisficing. « Or as stated by Farmer (1995: 70): „Notions of bounded rationality, or of actors as rule-followers, run the danger of 'putting the blamer on individual humans' limited cognitive abilities, but fail to recognize that it is the open, changing, nature of the social world which is at the root of the sunrealisticnessı of the neoclassical rational actor and all its various mutated forms." 
In the context of The General Theory, the unknown should be understood literally (Lawson 1985). In the case of The General Theory, we have to talk about uncertainty in a strong sense (a type of fundamental uncertainty). Dow (2004: 55I - 552) explains Keynes's understanding of uncertainty as follows:

"For Keynes, the significance of uncertainty for economics follows from the nature of the economic system, which does not satisfy the conditions for certain knowledge. He saw social systems as being organic, involving complex interrelationships within an evolving structure of institutions and with individual behaviour being both social and in general non-deterministic. This was his svision s of economic reality, that is, his ontology."

We simply do not know what the future outcomes would be, because the future has yet to be created. In this situation, some of the problems caused by uncertainty cannot be overcome by individuals gaining better cognitive skills. We may become more knowledgeable about present economic phenomena, but this does not automatically entail that we know what will happen in the future. In such an understanding, the economic system is not an ergodic system. It is not a simple deterministic system. It is a complex, changeable, and path-dependent system; therefore, as we have learnt from history, it is non-ergodic in its nature. For Dequech (1997b: 24),

"non-ergodicy is associated with the possibility of structural change and this possibility is a reason why the evidence available to economic decision makers is scant and knowledge not entirely reliable».

Or as (Davidson 1996: 482) puts it:

"Keynes's uncertain future involves a creative economic reality in the sense that the future can be permanently changed in nature and substance by actions of individuals, groups (e.g., unions, cartels), and/or governments, often in ways not completely foreseeable by the creators of change [...] In a non-ergodic environment [...] this existing market information does not, and cannot, provide reliable data for forecasting the future."

In his classic 1937 article, Keynes tried to highlight and compress his main messages from the 1936 The General Theory. In talking about his understanding of the fundamental type of uncertainty, he points out that:

"The sense in which I am using the term is that in which the prospect of a European war is uncertain, or the price of copper and the rate of interest twenty years hence, or the obsolescence of a new invention, or the position of private wealth owners in the social system of 1970. About these matters there is no scientific basis on which to form any calculable probability whatever. We simply do not know." (Keynes I937: II3 - II4)

As a consequence of this, we have to acknowledge that: 
whuman decisions affecting the future, whether personal or political or economic, cannot depend on strict mathematical expectations, since the basis for making such calculations does not exist; and that it is our innate urge to activity which makes the wheels go round, our rational selves choosing between the alternatives as best we are able, calculating where we can, but often falling back for our motive on whim or sentiment or chance" (Keynes 1936: 162 - 163).

Despite the existence of a fundamental type of uncertainty, households and firms have to act. They must decide what to do in the future, and would still act rationally if their behaviour were inspired by the following three guidelines, as derived from Keynes (1937: II4):

Firstly, we should accept that the present could be used »as a serviceable guide to the future«, although we actually know from using our past experience that the future must be different from the present. We thereby »largely ignore the prospect of future changes about the actual character of which we know nothing ".

Secondly, we should assume that present data on prices and output in general can be used as relevant information about future prospects until new evidence occurs that might cause us revise our expectations.

And finally, because we know that "our individual judgment is worthless" we should follow the behaviour "of the majority or the average « which might be better informed than the individual herself. In other words, we should act conventionally. ${ }^{7}$ Using these guidelines, we might have saved »our faces as rational, economic men " (Keynes 1937: II4) although in substance, this agent of Keynes differs considerably from the neoclassical slot machine man of Frank Knight. However, because the future almost with certainty would be different from the present, households and firms following the three stated guidelines are bound to make mistakes because their behaviour in practice is based, as Keynes points out, on a rather flimsy foundation. It is »subject to sudden and violent changes« (Keynes 1937: II4). As a result Keynes obtains:

"The practice of calmness and immobility, of certainty and security, suddenly breaks down. New fears and hopes will, without warning, take charge of human conduct. The forces of disillusion may suddenly impose a new conventional basis of valuation. All these pretty, polite techniques, made for a well-panelled board room and a nicely regulated market, are liable to collapse [...] I accuse the classical economic theory of being itself one of these pretty, polite techniques which tries to deal with the present by abstracting from the fact that we know very little about the future

7 As Runde (2003: 49) points out, Keynes contributed "an extremely rich account of how investors form expectations by falling back on conventions: the practice of assuming that the existing situation will continue indefinitely except insofar as there are definite reasons to except a change, the practice of taking current market evaluations as scorrect relative to existing knowledge, and the practice of copying the behaviour of other market participants who find themselves in a similar situation«. So to act conventionally is to accept that the behaviour of the individual is an interdependent kind of behaviour. See for example Davis (1997). 
[...] The orthodox theory assumes that we have a knowledge of the future of a kind quite different from that which we actually possess. This false rationalisation follows the lines of the Benthamite calculus. The hypothesis of a calculable future leads to a wrong interpretation of the principles of behaviour which the need for action compels us to adopt, and to an underestimation of the concealed factors of utter doubt, precariousness, hope and fear.« (Keynes I937: II4 - I22)

To act conventionally, as pointed out by Dequech (I997C), is a way to try to overcome the existence of a fundamental type of uncertainty. We possess some kind of knowledge about the workings of the social world that allows us to believe in the stability of at least some social practices. As pointed out by Lawson (1985: 917), "through partaking in social practices [...] people obtain direct knowledge of ways of getting by«. Different groups of individuals may learn about different kinds of social practices, and that is why "different societies or forms of organisation of society will give rise to different motives and so behaviour" (Lawson 1985: 917).

Individuals can behave rationally in their economic decision-making process in more than just one way. To act economically on conventions rather than on rational expectations, as we understand the term in modern macroeconomics, is to acknowledge that relevant economic behaviour is conducted in historical time at a given place under some given institutional framework. ${ }^{8}$ In this sense, individual economic behaviour is unique. As a consequence of this understanding, according to Keynes, economic theories have to depict some degree of realism. ${ }^{9}$ Furthermore, to act conventionally might also ensure a less volatile economic development, which in itself might strengthen and further reinforce the conventions held by the public as has been argued by Dequech (1997c). And finally, to accept that people act on different social practices is to accept the case of methodological pluralism. In such an environment, no single theory is capable of considering all the relevant factors in a changing economic context, as pointed out by Dow (2006). ${ }^{\circ}$

8 "Rules and conventions, that is, anchored individual behaviour, whether in ethics, politics or economic life, and we thus only grasped the behaviour of individuals fully when we understood how it came to be subsumed under society's rules and conventions." (Davis 1997: 208)

9 As pointed out by Dow (2003: 2I4): "His starting point was realist, namely the existence of a real world, however poorly we understand it. Furthermore, what he did know about the real world, based on experience, was that it is complex and evolving, which explains the limitations of our understanding." Or as Arestis (1996: II6) explains: "Theories should be relevant in that they should represent reality as accurately as possible and should strive to explain the real world as observed empirically."

Io "The argument then is not just that there are limitations to the human capacity for knowledge which prevent us from identifying a single best approach to knowledge which would satisfactorily explain lawlike behaviour. The argument is further that the absence of deterministic behaviour of individuals and the capacity for the conventions and institutions which condition their behaviour to evolve in undeterministic ways means that there is no set of economic laws to be found [...] Not only are economists better equipped to understand that behaviour and its consequences, if questions are approached from a variety of approaches (and indeed a variety of questions asked), but we should expect theory to change as the nature of the reality changes« (Dow 2006: I2 - I3). 


\section{Some macroeconomic implications}

Seen from the perspective of critical realism, we should try to obtain a closer correspondence between economic statements and theories, and real life behaviour. However, we will never obtain a one-to-one representation of reality. ${ }^{\text {II }}$ Of course, hardly any reasonable neoclassical economist would claim that households and firms actually conduct their behaviour in such a way as stipulated by the rigid slot machine man of Frank Knight. The traditional rational economic man of standard economic textbooks is only an actor. But the world view (or "mode of thought «, as Sheila Dow has termed $\mathrm{it}^{\mathrm{r}}{ }^{2}$ ) that follows from an acceptance of the visions represented by the rational economic man matters very much indeed when individual households and firms conduct their economic activities. Such a world view goes hand in hand with an acceptance of allowing the macroeconomic universe to become an ergodic economic system, as indicated in Table I, where this traditional kind of idealised economic behaviour representing modern mainstream macroeconomic thinking (New Classical as well as New Keynesian macroeconomics) is confronted with a post-Keynesian alternative representing a non-ergodic macroeconomic system. In such a system, as stated above in Section 4, we know that households and firms behave less than perfectly. This is not so much a consequence of a lack of cognitive abilities, as argued by the advocates of bounded rationality, but rather due to the existence of a fundamental type of uncertainty.

Although New Classical and New Keynesian macroeconomics may differ theoretically - e.g. New Keynesians accept some kind of rigidity, especially in the labour market, and imperfection (in the goods markets) while the New Classicals, with their focus on unexpected exogenous shocks as the main explanation of economic fluctuations, do not - they basically accept and use the same kind of methodology. Both schools argue that economic behaviour of the representative economic agent is of an optimising inter-temporal character, and that this behaviour has to be studied and analysed within a general equilibrium framework using rational expectations. As an alternative, post-Keynesians operate with a non-ergodic approach: the macroeconomic system is an open and evolutionary economic system (Chick/Dow 2005).

If one compares the two opposing kinds of individual behaviour as represented in Table I, we could talk about what Dow (1996: IO - I3) has termed »the Cartesian/Euclidean mode of thought« versus »the Babylonian mode of thought«. The first represents modern

II As Krugman (1998: 19) argues: „Economic theory is [...] a menagerie of thought experiments [...] that are intended to capture the logic of economic processes in a simplified way." And that is why we have to acknowledge that: »Theories are the outcome of the interaction of external reality with the theorist's understanding of it [...] The formulation of theories in economics [...] represents an attempt to deal with the fact that we can never attain a state of complete knowledge about the past, and even less about the future." (Dow 1996: 4-9).

I2 The concept "mode of thought « is defined by Dow (1996: IO) as follows: »By mode of thought is meant the way in which arguments (or theories) are constructed and presented, how we attempt to convince others of the validity or truth of our arguments. It is concerned as much with the rhetoric used as means of communication as with the logical structure of the argument." 
mainstream macroeconomics. Cartesian/Euclidean thought is characterized by an axiomatic approach that

"lends itself to formalism; classical mechanics and general equilibrium theory are excellent examples of closed theoretical systems [focusing] exclusively on certain (at least in principle) knowledge [and where] mathematics is thus regarded as the apex of scientific purity" (Dow I996: I4 - II).

The post-Keynesian alternative is quite different, employing

"several stands of argument which have different starting points and which, in a successful theory, reinforce each other; any argument, therefore, does not stand or fall on the acceptability of any one set of axioms. Knowledge is generated by practical applications of theories as examples, using a variety of methods [...] Argument in the Babylonian style is thus conditioned by the problem at hand, employs a range of methods suited to the problem, and these methods cannot be combined into one formal deductive argument without drastically changing their nature [...] The Babylonian approach [...] is characterized by organicism. This may stem from the view that the subject-matter of science is itself organic; or it may stem from the view that the subject-matter is ultimately unknowable in any complete sense, so that the most appropriate knowledge system for understanding it is organic [...] Babylonian thought is holistic in the sense that the binding factor of theories is a general perception of how the system as a whole works [...] The rationale for the Babylonian mode of thought is that reality is too complex to yield much certain knowledge [...] Babylonian thought represents the choice of building up rational grounds for belief in propositions, even if most of the underlying knowledge is held with uncertainty.«(Dow I996: I2 - I8) $)^{13}$

To acknowledge the existence of a fundamental type of uncertainty is to accept path dependency and irreversibility as core elements. As a consequence, the macroeconomic universe becomes a changeable system which could not be modelled in a traditional inter-temporal general equilibrium framework (Lang/Setterfield $2006-7$ ). Macroeconomics is thus more than what could be captured within the framework of a dynamic stochastic general equilibrium model. As explained by Leijonhufvud (2008: 93):

"The valid complaint is that general equilibrium theory does not help us understand the kind of disasters which originally motivated the emergence of macroeconomics as a distinct subdiscipline. This is a good enough reason to resist the total reabsorption of macroeconomics into dynamic stochastic general equilibrium theory."

I3 For a presentation of Keynes's mode of thought in his General Theory see Chick (2003). 
Table I: Two macroeconomic world views

\begin{tabular}{|c|c|}
\hline \multicolumn{2}{|c|}{ Two opposing kinds of individual behaviour } \\
\hline $\begin{array}{l}\text { Neoclassical behaviour } \\
\text { - the perfect optimising economic } \\
\text { agent } \\
\text { A basic deductive theory characterised } \\
\text { by: } \\
\text { I. A closed and stable deterministic eco- } \\
\text { nomic system } \\
\text { 2. The operation of the economic sys- } \\
\text { tem is ergodic } \\
\text { 3. The institutional set up is generally } \\
\text { very stable } \\
\text { 4. Economic behaviour is conducted in } \\
\text { ahistorical meta time } \\
\text { 5. Economics is basically a quantitative } \\
\text { science } \\
\text { 6. Economic evidence can be stated with } \\
\text { certainty } \\
\text { 7. Uncertainty is not of a fundamen- } \\
\text { the need to conduct economic poli- } \\
\text { tal character: we use rational expec- } \\
\text { tations } \\
\text { able } \\
\text { a stable and harmonious macroeco- } \\
\text { nomic outcome following an equilib- } \\
\text { rium path }\end{array}$ & $\begin{array}{l}\text { Post-Keynesian behaviour } \\
\text { - the restricted satisficing economic } \\
\text { agent } \\
\text { A basic inductive inspired theory char- } \\
\text { acterised by: } \\
\text { I. An open, social and changeable eco- } \\
\text { nomic system } \\
\text { The operation of the economic sys- } \\
\text { tem is non-ergodic } \\
\text { 3. Institutional changes are essential } \\
\text { 4. Economic behaviour is conducted in } \\
\text { historical time } \\
\text { 5. Economics is basically a qualitative } \\
\text { science } \\
\text { 6. It is better to be roughly right than } \\
\text { 10. Economic policy effects may be dif- } \\
\text { ficult to predict with certainty } \\
\text { The future is uncertain in a funda- } \\
\text { 8. The economic system is often in a dis- } \\
\text { mental way: expectations are not ra- } \\
\text { tional expectations } \\
\text { nomic outcomes (quaesitum) are of- } \\
\text { needed unique } \\
\text { thomic policy actions may be }\end{array}$ \\
\hline
\end{tabular}




\section{Some concluding remarks}

Since the days of Ricardo, economics has tried to become more scientific, attempting to imitate the natural sciences in rigour and precision. Methodologically, this has meant that we try to present economic statements and theories in mathematical terms. As described above, the economic behaviour of the representative economic agent in modern mainstream macroeconomics is of an optimising inter-temporal character that has to be studied and analysed within a general equilibrium framework using rational expectations. This makes the economic system an ergodic system. However, as Keynes has told us, not everything of relevance can be measured with the precision of the natural sciences. Economic data is of a much more heterogeneous nature than the data found in the hard sciences. Economic behaviour, and therefore economic science, has fundamentally to deal with motives, values and expectations. Therefore, the behaviour of the individual household and firm is less than perfectly rational. Seen from the post-Keynesians perspective, as stated in Sections 3 and 4, this has not primarily to do with a lack of cognitive abilities. Rather, it should be explained due to the existence of a fundamental type of uncertainty. As a consequence, the post-Keynesians give way to a non-ergodic approach: the macroeconomic system is an open and evolutionary economic system.

From the perspective of critical realism, we should try to get a tight correspondence between economic statements, theories and real life behaviour. Therefore, we have to accept that the economic system is, in principle, a non-ergodic system (Lawson 1999 and 1994). It appears, then, that the philosophy of the post-Keynesians and the advocates of critical realism overlap and go hand in hand. If the economic system is not a perfect and smoothly working system, with only a minimum of variation around an inter-temporal equilibrium trend, as posited by the post-Keynesians, the path is open for economic policy to play an active role. As demonstrated by the international economic crisis which began in 2007 , the economic policies of the United States, European countries and other countries are under severe challenge. We face monumental economic problems in the months and years ahead. To formulate and implement policies in the most effective way, we need to have a macroeconomic theoretical architecture that can cope with realities, rather than depend on well-formed models with little contact to realities. Given the present economic scenario, it is appropriate for the post-Keynesians to challenge modern mainstream macroeconomics. Nevertheless, criticism alone is not enough. Post-Keynesians need to develop an economic analysis that poses an alternative to mainstream macroeconomics (see for example the contributions of Wray/Forstater 2005). For such a framework, it is very important to stress that money matters. In addition, we should try to conduct economic policy in such a way so as to minimize the negative effects of the fundamental type of uncertainty. Credibility and a long-run perspective on economic policy - e.g. public expenditure programmes - matter if individual households and firms are to act on conventions or >rules-of thumb , as stated by Dequech (1997c). This might allow us to believe in the stability of at least some social practices. Focusing more on such social practices and trying to incorporate these as relevant in- 
stitutional factors in the economic analysis might make us more knowledgeable about how the business cycle develops.

\section{References}

Arestis, P. (1996): Post-Keynesian economics: Towards coherence, in: Cambridge Journal of Economics, 20, III - I35.

Blaug, M. (1997): Ugly currents in modern economics, in: Options Politiques, 3 - 8 (Septembre).

Blaug, M. (I999): The formalist revolution or what happened to orthodox economics after World War II, in: Backhouse, R., Creedy, J. (eds.), From Classical Economics to the Theory of the Firm - Essays in Honour of D.P. O'Brien, Cheltenham: Edward Elgar, 257 - 280.

Chick, V. (2003): Theory, method and mode of thought in Keynes's General Theory, in: Journal of Economic Methodology, I0, $307-327$.

Chick, V., Dow, S. (2005): The meaning of open systems, in: Journal of Economic Methodology, $\mathrm{I} 2,363-38 \mathrm{I}$.

Colander, David et al. (2007-8): Live and dead issues in the methodology of economics, in: Journal of Post Keynesian Economics, 30, 303-312.

Conlisk, J. (1996): Why bounded rationality?, in: Journal of Economic Literature, 34, 669 700.

Davidson, P. (1996): Reality and economic theory, in: Journal of Post Keynesian Economics, I8, $479-508$.

Davis, J.B. (1997): J.M. Keynes on History and Convention, in: Harcourt, G.C., Riach, P.A. (eds.), A second Edition ' of The General Theory - Vol. 2, Lodon / New York: Routledge.

Dequech, D. (I997a): A brief note on Keynes, unknown probabilities and uncertainty in a strong sense, in: History of Economic Ideas, I5(2), IOI - IIO.

Dequech, D. (1997b): Uncertainty in a strong sense: Meaning and sources, in: Economic Issues, 2, $2 \mathrm{I}-43$.

Dequech, D. (1997C): Different views on uncertainty and some policy implications, in: Davidson, P., Kregel, J. (eds.), Improving the Global Economy - Keynesianism and the Growth in Out put and Employment, Edward Elgar.

Dequech, D. (2007 - 2008): Neoclassical, mainstream, orthodox, and heterodox economics, in: Journal of Post Keynesian Economics, 30, 279-302.

Dow, S.C. (1996): The Methodology of Macroeconomic Thought, Cheltenham: Edward Elgar.

Dow, S.C. (2003): Probability, uncertainty and convention: economists' knowledge and the knowledge of economic actors, in: Runde, J., Mizuhara, S. (eds.), The philosophy of Keynes's economics: probability, uncertainty and convention, Routledge.

Dow, S.C. (2004): Uncertainty and monetary policy, in: Oxford Economic Papers, 56, 39 - 561.

Dow, S.C. (2006): Plurality in economics, University of Stirling, SCEME Working Paper No. II.

Dunn, S.P. (200I): Bounded rationality is not fundamental uncertainty: A Post Keynesian perspective, in: Journal of Post Keynesian Economics, 23, $567-587$. 
Farmer, M. (1995): Knowledgeability, actors and uncertain worlds, in: Dow, S.C., Hillard, J. (eds.), Keynes, Knowledge and Uncertainty, Edward Elgar.

Foley, D.K. (2004): Rationality and ideology in economics, in: Social Research, 7I, 329-342.

Haack, S. (2004): Science, economics, »Vision«, in: Social Research, 7I, 223- 234.

Heilbroner, R. (2000): The Worldly Philosophers - The Lives, Times and Ideas of the Great Thinkers, Penguin Books.

Hodgson, G.M. (2004): On the problem of formalism in economics, in: Post-Autistic Eeconomics Review, 28(I), I - 9, URL: http:/www.btinternet.com/pae_news/review/issue28.htm.

Keynes, J.M. (1936): The General Theory of Employment, Interest and Money, Macmillan: Cambridge University Press.

Keynes, J.M. (1937): The General Theory of employment, in: The Collected Writings of John Maynard Keynes, Vol. XIV: I09 - I23, Macmillan, Cambridge University Press 1973.

Krugman P. (1998): The accidental theorist, in: The Accidental Theorist. And Other Dispatches the Dismal Science, New York: W.W. Norton \& Company.

Lang, D., Setterfield, M. (2006 - 7): History versus equilibrium? On the possibility and realist basis of a general critique of traditional equilibrium analysis, in: Journal of Post Keynesian Economics, 29, I9I - 209.

Lawson, T. (1985): Uncertainty and economic analysis, in: The Economic Journal, 95,909- 927.

Lawson, T. (1994): The nature of Post Keynesianism and its link to other traditions: A realist perspective, in: Journal of Post Keynesian Economics, 16, $503-538$.

Lawson, T. (1999): Connections and distinctions: Post Keynesians and critical realism, in: Journal of Post Keynesian Economics, 22, 3 - I4.

Leijonhufvud, A. (2008): Moving on: Where to?, in: Forstater, M., Wray, R. (eds.), Keynes for the Twenty-First Century: The Continuing Relevance of The General Theory, New York: Palgrave Macmillan.

March, J.G. (1978): The 1978 Nobel Prize in economics, in: Science, 220 (4370), 858 - 86I.

McFadden, D. (1999): Rationality for economists?, in: Journal of Risk and Uncertainty, I9 $(\mathrm{I}-3), 73-$ IO5.

Morgan, M.S. (2006): Economic man as model man: Ideal types, idealization and caricatures, in: Journal of the History of Economic Thought, 28, I - 27.

Nelson, J.A. (2004): Is economics a natural science?, in: Social Research, 7I, 2II - 222.

Runde, J. (2003): On some explicit links between Keynes's `A Treatise on Probability` and 'The General Theory‘, in: Runde, J., Mizuhara, S. (eds.), The Philosophy of Keynes's Eeconomics: Probability, Uncertainty and Convention, London / New York: Routledge.

Simon, H.A. (1978): Rationality as process and as product of thought, in: The American Economic Review, 68, I - I6.

Simon, H.A. (1979): Rational decision making in business organizations, in: The American Economic Review, 69, 493 - 513.

Wray, R., Forstater, M. (eds.) (2005): Contemporary Post Keynesian Analysis, Cheltenham: Edward Elgar. 